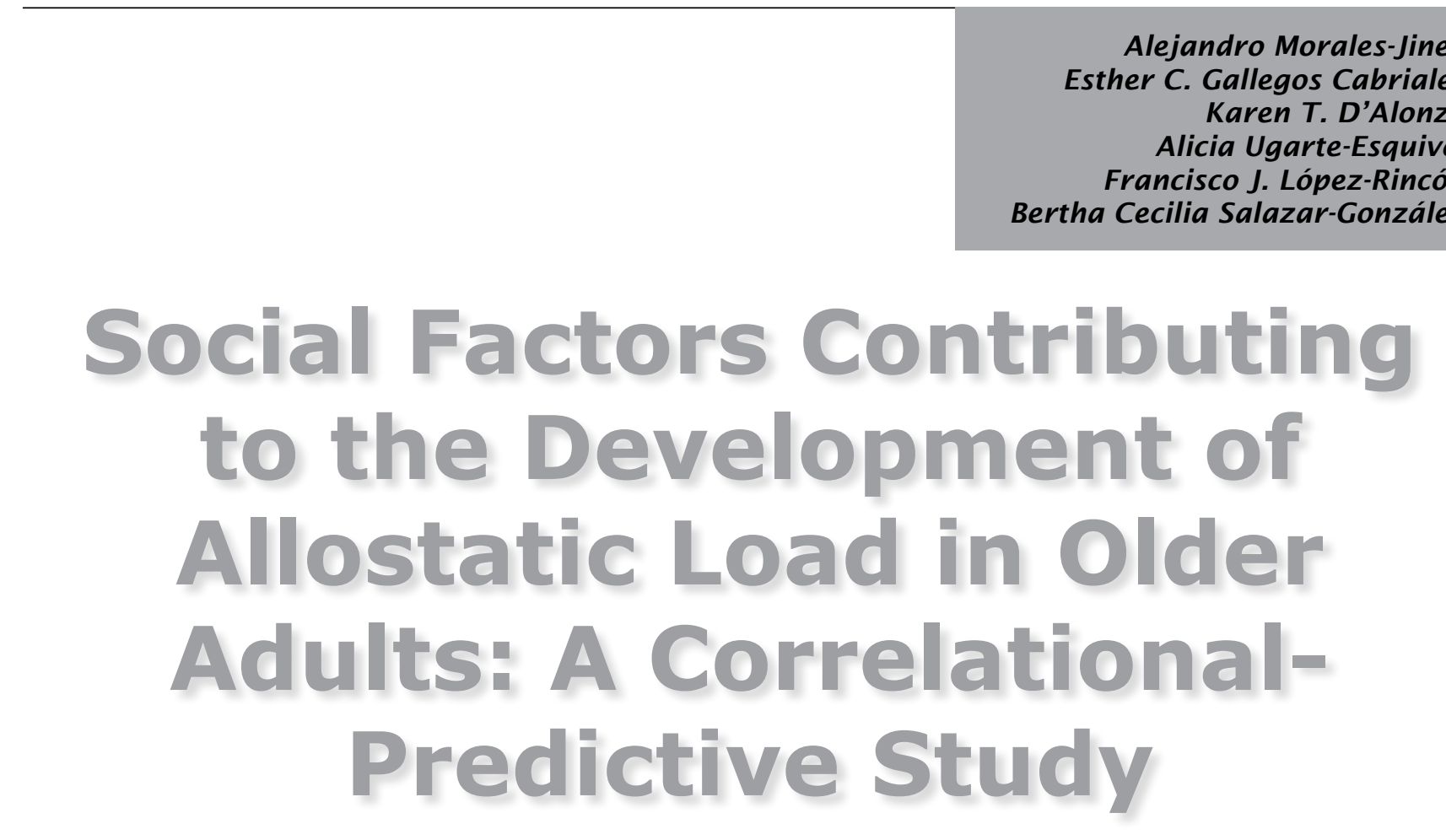

Topic: Promotion and prevention.

Contribution to discipline: This study is based on Betty Neuman's Systems Model and presents evidence on how social factors directly affect the health of older people.

\title{
ABSTRACT
}

Objective: To determine if social factors, such as housing conditions, satisfaction with one's house, neighborhood characteristics, social support, family relations and church attendance affect allostatic load in older adults. Materials and method: A correlationalpredictive, cross-sectional study was conducted. The instruments used were sociodemographic data, the perceived family relationships instrument, the Medical Outcomes Study-Social Support Survey and the abbreviated version of the Neighborhood Environment Walkability Scale. The allostatic load biomarkers used were: systolic and diastolic blood pressure, body mass index, waist circumference, waist-hip ratio, total cholesterol, high density lipoprotein, glycated hemoglobin, fibrinogen, and C-reactive protein. Sample size was estimated to contrast the no relation $\left(\mathrm{R}^{2}=0\right)$ hypotheis in a multiple lineal regression model with 11 covariables, with a significance level of .05 , power of $90 \%(.90)$, when coefficient of determination $\left(R^{2}\right)$ is .15 , resulting in a sample of 131 older adults. The statistical analysis included descriptive measures and generalized linear models. Results: The participants had either medium- or high-risk allostatic load. Multivariate

\section{doi: 10.5294/aqui.2018.18.3.5}

To cite this article / Para citar este artículo / Para citar este artigo

Morales-Jinez A, Gallegos-Cabriales EC, D’Alonzo KT, Ugarte-Equivel A, López-Rincón FJ, Salazar-González BC. Social factors contributing to the development of allostatic load in older adults: A correlational-predictive study. Aquichan. 2018; 18(3): 298-310. doi: 10.5294/aqui.2018.18.3.5

\footnotetext{
$1 \bowtie$ orcid.org/0000-0002-2463-7482. Universidad Autónoma de Coahuila, Mexico. alejandro_morales@uadec.edu.mx

2 orcid.org/0000-0003-3619-2596.Universidad Autónoma de Nuevo León, Mexico. esther.gallegoscb@uanl.edu.mx

3 orcid.org/0000-0002-3912-7442. Rutgers, The State University of New Jersey, United States of America. kdalonzo@rutgers.edu

4 orcid.org/0000-0002-4218-5889. Universidad Autónoma de Coahuila, Mexico. alicia.ugarte@uadec.edu.mx

5 orcid.org/0000-0003-0837-9396. Universidad Autónoma de Coahuila, Mexico. franciscolopezrinco@uadec.edu.mx

6 orcid.org//0000-0002-6610-8052. Universidad Autónoma de Nuevo León, Mexico. bertha.salazargn@uanl.edu.mx
}

Received: 16/04/2018

Sent to peer reviewers: 02/05/2018

Accepted by peers: $25 / 07 / 2018$

Aproved Submission: 21/08/2018 
linear regression model analysis showed that better housing conditions, satisfaction with own house, presence of dead-end streets, and church attendance reduce allostatic load, while dangerous traffic increases allostatic load. Conclusions: There are several social factors contributing to the development of allostatic load in older adults. It is necessary to create nursing care strategies toward the social environment to decrease allostatic load in older adults.

\section{KEYWORDS}

Allostasis; aging; family relations; residence characteristics; social support (Source: DeCS).

\section{Factores sociales que contribuyen al desarrollo de la carga alostática en adultos mayores: un estudio correlacional-predictivo}

\section{RESUMEN}

Objetivo: determinar si factores sociales como las condiciones de vivienda, la satisfacción con la casa, las características del vecindario, el apoyo social, las relaciones familiares y la asistencia a la iglesia contribuyen al desarrollo de la carga alostática en los adultos mayores. Materiales y método: se realizó un estudio correlacional y predictivo de corte transversal. Los instrumentos utilizados fueron una hoja de datos sociodemográficos, el instrumento de relaciones familiares percibidas, el cuestionario de Apoyo Social y la Escala de Movilidad Activa en el Entorno Comunitario, versión corta. Los biomarcadores de carga alostática utilizados fueron: presión arterial sistólica y diastólica, índice de masa corporal, circunferencia de la cintura, relación cintura-cadera, colesterol total, lipoproteína de alta densidad, hemoglobina glicosilada, fibrinógeno y proteína C-Reactiva. La muestra se calculó para para el contraste de la hipótesis de no relación $\left(R^{2}=0\right)$, en un modelo de regresión lineal múltiple con 11 covariables, con un nivel de significancia del .05 y una potencia del $90 \%$ (.90), cuando el coeficinete de determinación poblacional $\left(\mathrm{R}^{2}\right)$ es .15, tamaño de muestra que resultó en 131 adultos mayores. El análisis estadístico incluyó medidas descriptivas y modelos lineales generalizados. Resultados: los participantes tenían un riesgo medio 0 alto de carga alostática. El análisis del modelo de regresión lineal multivariante mostró que las mejores condiciones de vivienda, la satisfacción con la propia casa, la presencia de calles sin salida y la asistencia a la iglesia reducen la carga alostática y que el tráfico peligroso aumenta la carga alostática. Conclusiones: existen varios factores sociales que contribuyen al desarrollo de la carga alostática en adultos mayores. Es necesario crear estrategias de cuidado de enfermería hacia el entorno social para disminuir la carga alostática en el adulto mayor.

\section{PALABRAS CLAVE}

Allostasis; envejecimiento; relaciones familiares; características de la residencia; apoyo social (Fuente: DeCS). 


\section{Fatores sociais que contribuem para o desenvolvimento da carga alostática em idosos: um estudo preditivo correlacional}

\section{RESUMO}

Objetivo: determinar se fatores sociais, como as condições de moradia, a satisfação com a casa, as características do bairro, 0 apoio social, as relações familiares e a frequêencia à igreja afetam a carga alostática em idosos. Materiais e método: um estudo de correlação transversal e preditivo foi realizado. Os instrumentos utilizados foram dados sociodemográficos, o instrumento de relações familiares percebido, o Medical Outcomes Study-Social Support Survey e a Abbreviated Neighborhood Environment Walkability Scale. Os biomarcadores de carga alostática utilizados foram: pressão arterial sistólica e diastólica, índice de massa corporal, circunferência da cintura, relação cintura-quadril, colesterol total, lipoproteína de alta densidade, hemoglobina glicada, fibrinogênio e proteína C-reativa. A amostra foi calculada para o contraste do hipóseo de nenhuma relação $(R 2=0)$, em um modelo de regresión múltiple linear con 11 covariáveis, com um nível de significância de 0.05 e uma potencia de $90 \%$ (0.90), quando o coeficiente de determinação populacional (R2) es .15, o tamanho da amostra resultou em 131 idosos. A análise estatística incluiu medidas descritivas e modelos lineares generalizados. Resultados: os participantes tinham risco médio ou alto de carga alostática. A análise multivariada do modelo de regressão linear mostrou que melhores condições de moradia, satisfação com a casa própria, presença de ruas sem saída e freqüência à igreja reduzem a carga alostática e o tráfego perigoso aumenta a carga alostática. Conclusões: existem vários fatores sociais que contribuem para 0 desenvolvimento da carga alostática em idosos. É necessário criar estratégias de cuidados de enfermagem em direção ao ambiente social para diminuir a carga alostática no idoso.

\section{PALAVRAS-CHAVE}

Alostase; envelhecimento; relações familiares; características da residência; apoio social (Fonte: DeCS). 


\section{Introduction}

The world is undergoing an accelerated aging process. In $2015,12.3 \%$ of the world's total population were older adults; this figure will increase to $21.5 \%$ by the year 2050 (1). Latin America expects a higher percentage of growth in the older adult population, from $11 \%$ in the 2017 to an estimated $25 \%$ in a span of 35 years (2). These demographic and epidemiological changes are influenced by the social environment, birth reduction and the technological advances in health care. The World Health Organization acknowledged the existence of social determinants that may either favor or negatively affect an individual's health. The social determinants of health are defined as the conditions in which people are born, grow, live, work, and age. If the conditions are not favorable for an individual, they can become a cause of stress, which can have an impact on health $(3,4)$.

Stressful situations of daily life, as well as the environment, may trigger a series of biochemical reactions aimed at maintaining body stability, known as allostasis. The body reacts by changing internal parameters in an attempt to adapt to the demand $(5,6)$. Once the older person consciously detects a situation as stressful, a biochemical reaction is generated to achieve allostasis or adaptation to the perceived threat. However, if the adaptation process does not occur, the allostatic load arises. Allostatic load is defined as the accumulated physiological wear and tear that results from poor adaptation to environmental stressors. Elevated allostatic load involves the abnormal functioning of primary mediators such as cortisol and secondary mediators such as C-reactive protein (CRP), fibrinogen, blood pressure, total cholesterol, high-density lipoproteins (HDL), glycosylated hemoglobin, among others $(4,7,8)$.

Chronic diseases such as obesity, diabetes, cancer, cognitive decline and heart disease have been associated with social determinants of health, specifically the social environment, an aspect that is relevant in the case of older adults due to their vulnerability $(3,9,10)$. The evidence generated in European countries and North America shows that social factors such as socioeconomic status, educational level $(4,7,11,12,13)$, gender, ethnicity, occupational hierarchy $(11,14,15)$, church attendance $(16,17)$, and neighborhood's socioeconomic status (18, $19,20,21$ ) have being studied in relation to allostatic load. Low neighborhood socioeconomic level was associated with higher allostatic load $(18,19,20,21)$, the participant's poorer self rated health, more difficulty doing daily activities, and less physical ac- tivity in Taiwanese women (22), while religiosity was associated to lower allostatic load $(16,17)$.

Studies in Latin America have addressed the association between cortisol, a primary mediator of allostatic load, and its relation with social factors such as education, income, and wealth. The research results indicate no significant association with these social factors and cortisol level in a sample of Latin American older adults (23). Another study in Puerto Rico indicates that low neighborhood socioeconomic status is related to higher allostatic load (24). No research was found on social factors and allostatic load in Mexico.

This study is based on the Neuman Systems Model (NSM), which visualizes the person as a holistic system composed of five variables: physiological, psychological, sociocultural, developmental, and spiritual. These variables interact with each other and are in constant relation with the environmental stressors. Stressors have the ability to produce tension in the client and cause a negative, positive, or neutral effect, which is manifested by reactions in any of the five variables of the basic system; in this case, the physiological variable was taken into account (25).

The degree of reaction to a stressor depends on the resources available to the client to deal with the situation, the type of stressor or the amount of stressors that try to enter the system. This research focused on two types of stressors: interpersonal and extrapersonal. The interpersonal stressors are forces of the external environment occuring outside the boundaries of the client systema at proximal range (family and social support, among others), and the extrapersonal ones are external environmental interaction forces occuring outside the boundaries of the client system at distal range (characteristics of the neighborhood and of the dwelling). When the older adult does not have the ability to cope with stressors (flexible line and normal line of defense), stability is lost and defense mechanisms are activated (line of resistance). If there are insufficient resources to address the threat, signs and symptoms occur that reflect that reflect the alternation in the well-being of the client (25).

To summarize, there is still controversy between the association of social factors and allostatic load. Many studies do not consider social factors as having important direct effects on health; rather, social factors are seen as secondary influences $(22,23$, 
26). More specifically, the characteristics of the neighborhood acting as a source of stressors for allostatic load in older adults have not been studied and, in Latin America, there are a few studies of allostatic load and social factors in older adults. Detecting early risks of health due to social factors in older adults is important for nursing, to reduce or prevent further complications and diseases and to contribute to the overall quality of life and well-being (27). The aim of this research was to determine if social factors - particularly neighborhood characteristics, church attendance, and perception of family relationships - contribute to the development of allostatic load in a sample of community dwelling elders.

\section{Materials and Method}

A quantitiave, correlational-predictive (28), prospective and cross-sectional design was used. The sample consisted of older adults (60 years old and older) living in the Monterrey (Mexico) metropolitan area. A non-probabilistic convenience sampling was used. Participants were recruited from a public senior club and a church. Participants were excluded if they had suffered an acute myocardial infarction during the 6 months prior to the study or if they had had liver problems, as there are consecuences of allostatic load being present in the older adults and liver problems modify the results of the fibrinogen. Sample size was estimated using the nQuery Advisor version 4 software (29). For a significance level of .05 and $90 \%$ power, with a multiple regression model and $\mathrm{R}^{2}$ $=.15$, the resulting sample size of 131 subjects was calculated.

\section{Study variables}

A sociodemographic data sheet was used to register age, sex, marital status, number of years of education, occupation, current diseases, place of residence, housing satisfaction, religion, number of religious services attended weekly, and monthly income, systolic and diastolic blood pressure, height, weight, BMI, waist and hip circumference, and waist-hip ratio were also assessed.

Social factors considered as stressors in this study were: perception of housing conditions, satisfaction with one's house, neighborhood characteristics, social support, church attendance, and family relations, because the allostatic load is the result of multiple stressors of the physical, psychosocial and environmental type. The aging itself involves several psychosocial changes, and the selected stressors are those that older adults face frequently, according to the literature $(7,26)$.
The Perception of Family Relations Test in elders (30) evaluates the following dimensions of family relationships: boundaries, communication, role development, support system, hierarchy, and tolerance. The instrument has 30 items with a five-point Likertscale; scores range from 30 to 150 points. Authors report a Cronbach's alpha coefficient of 0.90 ; in this study, a coefficient of 0.89 was obtained. Higher scores represent better family relationships. The instrument is categorized as follows: 146 to 150 points $=$ very harmonious family relationships; 140 to 145 points $=$ harmonious family relationships; 129 to 139 points = little harmonious family relationships; and 30 to 128 points = disharmonious family relationships. Scores were transformed into an index of $0-100$ points to compare among other instruments.

The Medical Outcomes Study-Social Support Survey (MOSSSS) is a tool that measures the structural and functional dimensions of social support. The Spanish-language tool reports a Cronbach's alpha coefficient of 0.94 (31), similar to the value obtained in this study of Alpha $=0.95$. The instrument consists of 19 items on a five-point Likert-scale, ranging from "never" to "always," plus one question about social network size. Scores range from 19 to 95 points. The higher the score, the higher the perceived social support. An index of 0-100 points was obtained.

The Abbreviated Neighborhood Environment Walkability Scale (NEWS-A) measures the perceived characteristics of the neighborhood. Cerin and colleagues validated the NEW-A in 16 neighborhoods of County King, Washington, and reported a Cronbach's Alpha of 0.80 (32), and the Alpha was 0.62 in our study. Fifty-four items were used corresponding to the following dimensions: (a) type of housing in the neighborhood, (b) distance to relevant sites, (c) service accessibility, and (d) neighborhood security. These four dimensions break into 12 sub dimensions. The NEWS-A uses a five- and four-point Likert-type response patterns. The five-point response pattern assesses types of houses in the neighborhood, and these response options range from: none $=1$, to all of them $=5$. The four-point response pattern is used with the dimensions of service accessibility, streets conditions, and neighborhood security, and the response options are: strongly disagree $=1$, to strongly agree $=4$ points. The measurement of distance to relevant sites is based on the approximate time in minutes an older adult estimates it takes him or her to get from their house to nearby places. The responses are: 1-5, 6-10, 1120, 20-30 minutes, and more than 30 minutes. In cases where the respondent could not provide an estimation, the response was 
considered to be more than 30 minutes. Index points of $0-100$ were obtained for the whole instrument applied, and for each of the 12 sub-dimensions separately.

The selection of specific biomarkers and the method for calculation of a specific score differ widely in the literature. Thus, following the methods of Seeman et al. (33), a measure of allostatic load ( $A L)$ was designed to summarize levels of physiological activity across a range of regulatory systems, including: systolic blood pressure, diastolic blood pressure, body mass index, waist circunference, waist-hip ratio, total cholesterol, high-density lipoprotein (HDL), glycated hemoglobin, fibrinogen, and C-reactive protein. To construct an allostatic load index, each biomarker was given a value of zero (low risk) if it was found within normal levels and a value of one (high risk) if the biomarker was above reference values. In the case of HDL, a zero (low risk) was assigned when this biomarker was high, and a value of one (high risk) when concentration levels were low. Finally, all biomarkers and anthropometric measurements were summed up. The possible range was 0 to 10. Participants were categorized as follows: the "low risk" category included subjects whose biomarkers and anthropometric measures were unaltered, "medium risk" when two or three biomarkers were altered, and "high risk" when four or more biomarkers and anthropometric measures were altered (34). Biomarkers measurements were performed as follows:

Blood pressure. Blood pressure measurement was carried out using a mercury sphygmomanometer and a stethoscope. Blood pressure was taken twice on the participants' left arm after 10 minutes of rest in the sitting position; values were registered in the data sheet. Measurements were averaged to obtain an overall systolic and diastolic blood pressure.

Body mass index. We use the Quetelet formula, wherein the participants' weight in kilograms was divided by their height in square meters $\left(\mathrm{kg} / \mathrm{m}^{2}\right)$. To calculate weight and height, an electronic scale with infrared stadiometer was used, which was calibrated and data was transcribed on the data sheet.

Waist-hip ratio (WHR). WHR was the result of the waist circumference divided by hip circumference. To calculate waist and hip, a fiberglass tape measure was used, and we followed the protocol described by the World Health Organization (35).

Cholesterol, HDL, glycated hemoglobin, fibrinogen, and Creactive protein. One of three blood samples per participant was analyzed for C-reactive protein, total cholesterol, HDL, glycated hemoglobin, and fibrinogen levels; these blood samples were collected in tubes by qualified personnel, stored on a cooler and transported to the laboratory for immediate glycated hemoglobin analysis; the other two samples were centrifuged, and serum was frozen for HDL, C-reactive protein, fibrinogen, and total cholesterol testing the following week.

The following procedures were used for each biomarker measurement: turbidimetry for glycated hemoglobin, coagulometric method for fibrinogen, colorimetry and turbidimetry for C-reactive protein. Total cholesterol and HDL were measured using the enzymatic, coagulometric, and selective ion methods. The biomarkers cut-off points proposed (36) are shown in Table 1.

Table 1. Allostatic load biomarker cut-off points

\begin{tabular}{|c|c|c|}
\hline & Biomarker & Cut-off point \\
\hline Total choles & terol (mg/dL) & $>240$ \\
\hline High densit & lipoprotein (mg/dL) & $<36$ \\
\hline Glycated he & moglobin (\%) & $>7.1$ \\
\hline Fibrinogen & $\mathrm{mg} / \mathrm{dL})$ & $>336$ \\
\hline C-reactive & rotein (mg/dL) & $>0.3$ \\
\hline Systolic blo & d pressure $(\mathrm{mmHg})$ & $>148$ \\
\hline Diastolic bl & od pressure $(\mathrm{mmHg})$ & $>83.3$ \\
\hline Waist-hip r & tio (WHR): & $>0.94$ \\
\hline Body mass & ndex (BMI) & $>25$ \\
\hline We & Female & $>85$ \\
\hline 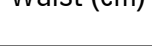 & Male & $>95$ \\
\hline
\end{tabular}

Source: Adapted from Gruenewald, Seeman, Karlamangla, and Sarkisian (36).

This study was approved by the Ethics Committee of the Autonomous University of Nuevo León School of Nursing (FAEN-D-1007 Record; IRB 00002060 Record). Once the project was approved, agreements were made with corresponding authorities to gather data at the selected sites. The principal investigator explained the study and invited potential participants. Participants who agreed and met the selection criteria signed an informed consent. Participants were informed in writing and verbally about the requisites for laboratory sample drawing (12-hour fasting) and the date of the appointment. After the blood sample was drawn, sociodemographic data and anthropometric measures were collected. Each 
participant was given another appointment to receive his or her laboratory results and to complete the instruments.

\section{Statistical analysis}

The SPSS software version 22 for Mac was used for data analysis. Descriptive analysis was calculated for the characteristics of participants and study variables. Alpha Cronbach's coefficients were reported in the measure section. Generalized linear models were used to determine the contribution of social factors on allostatic load. A $p$ value of .05 was used to determine significance.

\section{Results}

Of the 131 older adults in the final sample, 92.4\% [121] were female. The mean age was 73.5 years old $(S D=6.75$, range 60 - 89 years), and of years of school was 3.68 years $(S D=3.09$, range $0-15$ years). Fifty-six percent of participants $(n=74)$ said they were widowed, $31.3 \%$ [41] were married, and the rest were either divorced, or single. The majority of participants $(85.5 \%, n$ $=112$ ) were homemakers, $11.5 \%$ [15] described themselves as retired, and 3\% [4] had their own business or volunteered for a non-governmental organization. The mean church attendance was 1.63 times per week (median $=1, S D=1.72$ ).

Anthropometric measures for weight, height, body mass index, waist, hip, waist-hip ratio, systolic and diastolic blood pressure are presented in Table 2.

Average BMI and waist circumference, both in men and in women, were found to be high; however, average waist-hip ratio, systolic and diastolic blood pressure were normal. Only 30 (24.8\%) women, and 4 out of 10 men (40\%) had waist circumferences within the acceptable range.

Fibrinogen ( $n=102,78 \%)$, and C-reactive protein $(n=139,99 \%)$, total cholesterol $(n=19,14.5 \%$, glycated hemoglobin $(n=22,17 \%)$ were elevated, and high-density lipoprotein levels $(n=37$, $29 \%$ ) were low, indicating high-risk parameters for allostatic load.

Table 2. Anthropometric, clinical and biochemical descriptive data

\begin{tabular}{|c|c|c|c|c|c|c|c|c|}
\hline \multirow{2}{*}{\multicolumn{2}{|c|}{ Biomarker }} & \multirow{2}{*}{ Mean } & \multicolumn{2}{|c|}{ 95\% Confidence Interval } & \multirow{2}{*}{ Median } & \multirow{2}{*}{ SD } & \multirow{2}{*}{ Minimum } & \multirow{2}{*}{ Maximum } \\
\hline & & & LCL & UCL & & & & \\
\hline \multicolumn{2}{|l|}{ Weight $(\mathrm{kg})$} & 66.87 & 64.60 & 69.14 & 65.60 & 13.13 & 41.10 & 111.30 \\
\hline \multicolumn{2}{|l|}{ Height (cm) } & 149.00 & 147.00 & 150.03 & 148.00 & 9.00 & 129.00 & 183.00 \\
\hline \multicolumn{2}{|c|}{ Body Mass Index } & 30.14 & 29.29 & 31.00 & 29.66 & 4.96 & 19.50 & 49.50 \\
\hline \multirow{2}{*}{ Waist (cm) } & Female & 96.63 & 94.52 & 98.74 & 96.00 & 11.73 & 72.00 & 133.00 \\
\hline & Male & 98.40 & 86.96 & 109.84 & 104.00 & 15.99 & 70.00 & 125.00 \\
\hline \multicolumn{2}{|l|}{ Hip (cm) } & 108.07 & 105.64 & 110.50 & 106.00 & 14.04 & 85.00 & 197.00 \\
\hline \multicolumn{2}{|c|}{ Waist Hip Ratio } & 0.90 & 0.88 & 0.91 & 0.89 & 0.09 & 0.44 & 1.19 \\
\hline \multicolumn{2}{|c|}{ Systolic blood pressure $(\mathrm{mmHg})$} & 132.35 & 129.73 & 134.98 & 130.00 & 15.17 & 105.00 & 180.00 \\
\hline \multicolumn{2}{|c|}{ Diastolic blood pressure $(\mathrm{mmHg})$} & 84.23 & 82.56 & 85.91 & 85.00 & 9.69 & 65.00 & 125.00 \\
\hline \multicolumn{2}{|c|}{ Total cholesterol (mg/dl) } & 200.07 & 192.82 & 207.32 & 202.00 & 41.94 & 103.00 & 320.00 \\
\hline \multicolumn{2}{|c|}{ High density lipoprotein $(\mathrm{mg} / \mathrm{dL})$} & 48.21 & 45.71 & 50.71 & 44.00 & 14.46 & 28.00 & 95.00 \\
\hline \multicolumn{2}{|c|}{ C-Reactive protein (mg/dL) } & 1.22 & 1.10 & 1.35 & 1.10 & 0.72 & 0.20 & 5.00 \\
\hline \multicolumn{2}{|c|}{ Fibrinogen (mg/dL) } & 428.27 & 410.84 & 445.70 & 425.00 & 100.84 & 238.00 & 753.00 \\
\hline \multicolumn{2}{|c|}{ Glycated hemoglobin (\%) } & 6.16 & 5.97 & 6.35 & 5.90 & 1.11 & 4.00 & 11.60 \\
\hline
\end{tabular}

Source: Own elaboration. 
Twenty-one (16\%) subjects were classified as having medium allostatic load risk (two or three biomarkers above the cut-off point) and $84 \%$ [110] as having high risk (four or more altered biomarkers). There were no cases of low allostatic load risk.

A generalized linear model was used to determine the contribution of potential stressors. A total of 15 independent variables were entered into the equation and allostatic load as dependent variable, including perception of family relations, social support, and number of times per week attending church, and 12 subdimensions of the NEWS instrument accessibility of services, satisfaction with their house, distance to relevant sites, street aesthetics, general neighborhood characteristics, dangerous traffic, housing conditions, sloped streets, street connectivity, pedestrian infrastructure, dead-end streets, neighborhood security. The general model was significant:

$F_{(15,115)}=2.645 p<.05, \mathrm{R}^{2}=16 \%$ (Table 3).
When the backward elimination method was used, the explained variances improved $F_{(5,125)}=7.466, p<.001, \mathrm{R}^{2}=19.9 \%$.

Table 4 also shows that better housing conditions, satisfaction with own house, presence of dead-end streets, and church attendance reduce allostatic load, and that increase in dangerous traffic increases allostatic load.

\section{Discussion}

For Neuman (25), the person is an open system that is in constant interaction with the environment. In the environment, there are forces that can alter the basic structure or client's system. According to Neuman, a physiological variable can cause a serious imbalance to the client when he or she has insufficient resources to cope with stressors. In this study, the physiological variable was allostatic load, and a high proportion of participants fell under a high risk pf allostatic load (four or more altered biomarkers)

Table 3. Generalized Linear Model for social factors contributing to allostatic load in older adults

\begin{tabular}{|l|c|c|c|c|}
\hline \multicolumn{1}{|c|}{ Independent variable } & B & EE & $\boldsymbol{\beta}$ & $\mathbf{p}$ \\
\hline Housing conditions & -.011 & .005 & -.226 & .014 \\
\hline Sloped streets & .002 & .003 & .518 & .605 \\
\hline Street aesthetics & -.004 & .004 & -.086 & .393 \\
\hline Dead-end streets & -.008 & .003 & -.244 & .003 \\
\hline Pedestrian infrastructure & .000 & .007 & .002 & .987 \\
\hline Street connectivity & -.003 & .005 & -.068 & .528 \\
\hline Satisfaction with one's house & -.015 & .006 & -.218 & .023 \\
\hline Distance to relevant sites & -.171 & .207 & -.078 & .411 \\
\hline Family relationships & .000 & .012 & .004 & .977 \\
\hline Dangerous traffic & .012 & .004 & .271 & .007 \\
\hline Neighborhood security & -.003 & .005 & -.064 & .514 \\
\hline Accessibility to services & .005 & .006 & .097 & .357 \\
\hline Social support & -.005 & .008 & -.081 & .524 \\
\hline Neighborhood characteristics & .004 & .018 & .041 & .822 \\
\hline Church attendance & -.156 & .066 & -.195 & .019 \\
\hline
\end{tabular}

Source: Own elaboration. 
Table 4. Final Generalized Linear Model for social factors contributing to allostatic load in older adults

\begin{tabular}{|l|c|c|c|c|}
\hline \multicolumn{1}{|c|}{ Independent variable } & $\mathbf{B}$ & $\mathbf{E E}$ & $\boldsymbol{\beta}$ & $\mathbf{p}$ \\
\hline Housing conditions & -.014 & .006 & -.197 & .025 \\
\hline Satisfaction with one's house & -.012 & .004 & -.233 & .007 \\
\hline Dangerous traffic & .011 & .003 & .257 & .002 \\
\hline Dead-end streets & -.008 & .003 & -.244 & .003 \\
\hline Church attendance & -.156 & .066 & -.195 & .019 \\
\hline
\end{tabular}

Source: Own elaboration.

and less participants under a medium risk for allostatic load (two or three altered biomarkers), suggesting that the elder's physiological system was not able to overcome the imbalance.

Fibrinogen and $\mathrm{C}$-reactive protein were elevated in a high proportion of participants. Fibrinogen and C-reactive protein are produced in the liver, and life-styles, such as lack of exercise or physical activity and alcohol and tabacco consumption may affect the liver, and the rise of fibrinogen and C-reactive protein in conjunction with elevated BMI increase the risk for clots development and myocardial infarction. C-reactive protein is closely related to BMI due to inflammation processes. Most of the participants showed mean abdominal circumference and BMI above the established acceptable standards. According to the Neuman system, the model results of participants suggest they were not able to maintain the normal line of defense through healthy eating and exercise. Moreover, these results confirm those of the national health survey that revealed a higher prevalence of obesity among older adult populations in northern Mexican states $(37,25)$.

The environmental stressors to which the elderly person is subjected can be very diverse. From a physiological point of view, the body may reach a point where it cannot sustain regulation of basic processes to maintain an allostasis. This lack of regulation may then trigger illness, with the end result being a decreased quality of life for the elder. In this research, the interpersonal and extrapersonal stressors included neighborhood characteristics, housing conditions, satisfaction with one's house, presence of dead-end streets, and weekly attendance to church (26). The statistical analysis confirmed that interpersonal and extrapersonal stressors positively affected the explained variance of allostatic load, while dangerous traffic negatively affected the explained variance of the allostatic load. The positive effects of housing conditions and satisfaction with own house are supported by some authors, who found an association between satisfaction and better housing conditions, and well-being, and low pathology incidence among older adults $(38,39,40)$.

Results also showed that dangerous traffic increases allostatic load. Participants frequently reported feeling stressed by vehicles running at high speeds, because they feared accidents. In this regard, the literature review indicates that noise produced by heavy traffic has negative effects on the cardiovascular system, which also impacts allostatic load risk (41, 42, 43, 44). This study did not specifically inquire about vehicle noise, but it is assumed that noise comes with heavy traffic.

The presence of dead-end streets contributed as a protective variable; in this sense, participants pointed out that there was less traffic in these streets, and therefore less stress. Also, it was inferred that dead-end streets encouraged them to walk and get from one place to another in the neighborhood.

The Neuman System Model assumes that spiritual variable empowers the client toward well-being by positively directing spiritual energy for use first by the mind and then by the body, and the religion is an important component of spirituality (25). Attending religious services contributed to explain lower allostatic load. Religiousness, or the number of times per week that a person goes to church, has been reported as a protective agent against allostatic load, which plays a protective role among women, given that they tend to be more committed to religion (12), and in this research most of the participants in the present study were women. Another explanation might be the social networks developed while an elder attends church services, and that religiousness could enable them to cope better with health and social problems $(44,45,46)$. 


\section{Limitations}

Results cannot be generalized due to selection method (convenience sampling) and lack of enough men in the study. All the older adults lived in neighborhoods with similar characteristics, which could have affected variability and the ability to obtain more significant results. A neighborhood-based sampling strategy and the analysis of other variables such as vehicle noise and, particularly, family relations and social support, need to be approached from a qualitative perspective or other instruments.

As a final note, the ten biomarkers used in the present study are classified as secondary biomarkers (47). The incorporation of primary biomarkers such as cortisol, epinephrine, and norepinephrine could help to better understand whether such primary biomarkers are better explained by social factors.

\section{Conclusion}

The main concern of nursing is to maintain the elderly within a maximum level of well-being through actions aimed at reducing threats or stressors in the environment. This study contributes to the discovery of social factors that are stressful for the elderly and that have sometimes been minimized within the preventive practice of health.
According to the results of the study, the characteristics of the neighborhood and the housing conditions affect the physiological variable of the elderly. On the contrary, the number of times per week that the elder attends religious events, the good conditions of the home in which he lives, and being satisfied with his home were negatively associated with an elevated allostatic load.

The application of scientific evidence should be in primary and secondary prevention in order to strengthen the flexible line of defense and reduce the possibility that an interpersonal or extrapersonal stressor affects the elder adult. The results of scientific research need to generate more evidence to develop new assessments in the social aspect of elder adults. Likewise, these results can contribute to modify or generate political proposals to improve the health of our population older than 60 .

\section{Acknowledgments}

We would like to thank the National System for Integral Family Development (DIF) of Monterrey (Mexico) facilitating the collection of data and providing the use of their facilities during the investigation.

Conflict of interest: None was declared.

\section{References}

1. Global AgeWatch. Índice global de envejecimiento, AgeWatch 2015: Resumen Ejecutivo. [Internet] 2015. [Cited April 18, 2018] Available from: http://www.helpage.org/silo/files/ndice-global-de-envejecimiento-2015-resumen-ejecutivo.pdf

2. Aranco N, Stampini M, Ibarrarán P, Medellín N. Panorama de envejecimiento en America Latina y el Caribe [Internet] 2017. Available from: https://publications.iadb.org/bitstream/handle/11319/8757/Panorama-de-envejecimiento-ydependencia-en-America-Latina-y-el-Caribe.PDF?sequence $=3$

3. Braveman P, Gottlieb L. The social determinants of health: It's time to consider the causes of the causes. Public Health Rep. 2014; 129 (Supl 2): 19-31. doi: 10.1177/00333549141291S206.

4. Chen E, Miller GE. Socioeconomic status and health: Mediating and moderating factors. Annu. Rev. Clin. Psychol. 2013; 9: 723-749: doi: 10.1146/annurev-clinpsy-050212-185634.

5. Sterling P, Eyer J. Allostasis: A new paradigm to explain arousal pathology. In Fisher S, Reason J. Editors, Handbook of life stress, cognition and health. Chichester, England: Wiley; 1988. p. 629-649. Available from: http://retina.anatomy. upenn.edu/pdfiles/5446.pdf

6. Henry JP, Stephens PM. Stress, health, and the social environment: A sociobiologic approach to medicine. New York: Springer-Verlag; 2013. Available from: https://www.springer.com/la/book/9781461263654 
7. McEwen BS. The brain of stress: Toward an integrative approach to brain, body and behavior. Perspect. Psychol. Sci. 2013; 8 (6): 673-675. doi:10.1177/1745691613506907.

8. Gallo LC, Fortmann AL, Mattei J. Allostatic Load and the Assessment of cumulative biological risk in biobehavioral medicine: Challenges and opportunities. Psychosom. Med. 2014; 76 (7): 478-480. doi:10.1097/PSY.0000000000000095.

9. Marin MF, Lord C, Andrews J, Juster RP, Sindi S, Arsenault-Lapierre G, Fiocco AJ, Lupien SJ. Chronic stress, cognitive functioning and mental health. Neurobiol Learn Mem. 2011; 96: 583-595. doi: 10.1016/j.nlm.2011.02.016.

10. Kumar R. Social determinants of health among elderly: An anthropological study. International Journal of Research in Sociology and Social Anthropology 2013; 1 (1): 11-16. Available from: http://citeseerx.ist.psu.edu/viewdoc/download ?doi=10.1.1.403.9524\&rep=rep1\&type $=$ pdf

11. Seeman M, Merkin S, Karlamangla A, Koretz B, Seeman T. Social status and biological dysregulation: The "satus syndrome" and allostatic load. Soc Sci Med 2014; 118: 143-151. doi: 10.1016/j.socscimed.2014.08.002.

12. Robertson T, Popham F, Benzeval M. Socioeconomic position across the lifecourse \& allostatic load: Data from the West of Scotland twenty-07 cohort study. BMC Public Healt 2014; 14: 184-192. doi:10.1186/1471-2458-14-184.

13. Merkin SS, Karlamangla A, Roux AVD, Shrager S, Seeman TE. Lifecourse socioeconomic status and longitudinal accumulation of allostatic load in adulthood: Multi-ethnic study of atherosclerosis. Am J Public Health $2014 ; 104$ (4): e48-e55. doi: 10.2105/AJPH.2013.301841

14. Short SE, Yang YC, Jenkins TM. Sex, gender, genetics and health. Am J Public Health 2013; 103(s1): s93-s101: doi:10.2105/ AJPH.2013.301229.

15. Seeman T, Epel E, Gruenewald T, Karlamangla A, McEwen BS. Socio-economic differentials in peripheral biology: Cumulative allostatic load. Ann. N.Y. Acad. Sci. 2010; 1186: 223-239. doi: 10.1111/j.1749-6632.2009.05341.x.

16. Hill TD, Rote SM, Ellison CG, Burdette AM. Religious attendance and biological functioning: A multiple specification approach. J Aging Health 2014; 26 (5): 766-785. doi: 10.1177/0898264314529333.

17. Bruce MA, Martins D, Duru K, Beech BM, Sims M, Harawa N, Vargas R, Kermah D, Nicholas SB, Brown A, Norris KC. Church attendance, allostatic load and mortality in middle aged adults. Plos One 2017; 12 (5): e0177618. doi: 10.1371/journal. pone.0177618.

18. Ribeiro AI, Amaro J, Lisi C, Fraga S. Neighborhood socioeconomic deprivation and allostatic load: A scoping review. Int J Environ Res Public Health 2018; 15 (6): 1092. doi: 10.3390/ijerph15061092.

19. Gustafsson PE, San Sebastian M, Janlert U, Theorell T, Westerlund H, Hammarström A. Life-Course Accumulation of Neighborhood Disadvantage and Allostatic Load: Empirical Integration of Three Social Determinants of Health Frameworks. Am J Public Health 2014; 104 (5): 904-910. doi: 10.2105/AJPH.2013.301707.

20. Robinette JW, Charles ST, Almeida DM, Gruenewald TL. Neighborhood features and physiological risk: An examination of allostatic load. Health \& Place 2016; 41: 110-118. doi: 10.1016/j.healthplace.2016.08.003.

21. Schulz AJ, Metz G, Lachance L, Zenk SN, Johnson J, Stokes C, Mandell R. Do observed or perceived characteristics of the neighborhood environment mediate associations between neighborhood poverty and cumulative biological risk? Health \& Place 2013; 24: 1-22. doi: 10.1016/j.healthplace.2013.09.005.

22. Hu P, Wagle N, Goldman N, Weinstein M, Seeman TE. The associations between socioeconomic status, allostatic load and measures of health in older Taiwanese persons: Taiwan social environment and biomarkers of aging study. J. Biosoc. Sci. 2007; 39(4): 545-556. doi: 10.1017/S0021932006001556.

23. Dowd JB, Simanek AM, Aiello AE. Socio-economic status, cortisol and allostatic load: a review of the literature. Int. J. Epidemiol 2009; 38 (5): 1297-1309. Available from: https://academic.oup.com/ije/article/38/5/1297/666615

24. Jiménez MP, Osypuk TL, Arevalo S, Tucker KL, Falcon ML. Neighborhood socioeconomic context and change in allostatic load among older Puerto Ricans: the Boston Puerto Rican Health Study. Health \& Place 2015; 33: 1-8. doi: 10.1016/j. healthplace.2015.02.001.

25. Neuman B, Fawcett J. The Neuman Systems Model. USA: Pearson; 2011. 
26. Cockerham WC, Hamby BW, Oates GR. The social determinants of chronic disease. Am J Prev Med $2017 ; 52$ (1 Sipl 1): S5-S12. doi: 10.1016/j.amepre.2016.09.010.

27. Rosemberg MS, Li Y, Seng J. Allostatic load: a useful concept for advancing nursing research. J Clin Nurs 2017: 1-15. Available from: http://onlinelibrary.wiley.com/doi/10.1111/jocn.13753/abstract

28. Grove SK, Gray JR, Burns N. Investigación en enfermería: Desarrollo de la práctiva enfermera basada en la evidencia. España: Elsevier; 2016.

29. Elashoff DJ, Dixon JW, Crede MK, Fothenringham N. N’Query advisor. Release 4.0, [Study planning software]. Boston, M.A: Statistical solutions; 2004.

30. Espín AM, Quintero G, Bayarre H. Construcción de un instrumento para medir la percepción de las relaciones familiares del anciano. Estud Interdiscip Envelhec 2001; 3: 55-69. Available from: http://www.seer.ufrgs.br/index.php/RevEnvelhecer/article/view/4669/2587

31. Revilla L, Luna J, Bailón E, Medina I. Validación del cuestionario MOS de apoyo social en atención primaria. Medicina de Familia 2005; 6 (1): 10-18. Available from: http://www.samfyc.es/Revista/PDF/v6n1/03.pdf

32. Cerin E, Saelens BE, Sallis JF, Frank LD. Neighborhood Environment Walkability Scale: Validity and development of a short form. Med Sci Sports Exerc 2006; 38 (9): 1682-1691. doi: 10.1249/01.mss.0000227639.83607.4d.

33. Seeman TE, McEwen BS, Rowe JW, Singer BH. Allostatic load as a marker of cumulative biological risk: MacArthur studies of successful aging. Proc Natl Acad Sci USA. 2001; 98(8): 4770-4775. doi: 10.1073/pnas.081072698.

34. Seplaki CL, Goldman N, Wienstein M, Lin Y. Measurement of cumulative physiological dysregulation in an older population. Demography 2006; 43 (1): 165-183. doi: 10.1353/dem.2006.0009.

35. World Health Organization. Waist circumference and Waist-Hip ratio. Report of a WHO espert consultation. Geneve, Switzerland: WHO Press; 2011. Available from: http://apps.who.int/iris/bitstream/handle/10665/44583/9789241501491_ eng.pdf;jsessionid=D932C0F477FC1B04A5E95E380B7E29EE? sequence $=1$

36. Gruenewald TL, Seeman TE, Karlamangla AS, Sarkisian CA. Allostatic load and frailty in older adults. J Am Geriatr Soc 2009; 57 (9): 1525-1531. doi: 10.1111/j.1532-5415.2009.02389.x.

37. Encuesta nacional de salud y nutricion de medio camino 2016 (ENSANUT MC 2016). Informe Final de resultados. Instituto Nacional de Salud Pública: México (2016). Available from: https://www.gob.mx/cms/uploads/attachment/ file/209093/ENSANUT.pdf

38. Thomson H, Thomas S, Sellstrom E, Petticrew M. Housing improvements for health and associated socio- economic outcomes (Review). Cochrane Database of Systematic Reviews 2013; 2 (2). doi: 10.1002/14651858.CD008657.pub2.

39. Thomson H, Thomas S. Developing empirically supported theories of change for housing investment and health. Soc Sci Med 2015; 124: 205-2014. doi: 10.1016/j.socscimed.2014.11.043.

40. Adamkiewicz G, Spengler JD, Harley AE, Stoddard A, Yang M, Alvarez-Reeves M, Sorensen G. Environmental Conditions in Low-Income Urban Housing: Clustering and Associations With Self-Reported Health. Am J Public Health $2014 ; 104$ (9): 1650-1656. doi: 10.2105/AJPH.2013.301253.

41. Recio A, Linares C, Banegas JR, Díaz J. Road traffic noise effects on cardiovascular, respiratory, and metabolic health: An integrative model of biological mechanisms. Environ Res 2016; 146: 359-370. doi: 10.1016/j.envres.2015.12.036.

42. Röösli M. Health Effects of environmental noise exposure. Ther Umsh 2013; 70 (12): 720-724. doi: 10.1024/0040-5930/ $\mathrm{a} 000470$.

43. Münzel T, Gori T, Babisch W, Basner M. Cardiovascular effects of environmental noise exposure. Eur Heart J 2014 ; 35 (13): 829-836. doi: 10.1093/eurheartj/ehu030.

44. Schieman S, Bierman A, Ellison CG. Religion and Mental Health. In: Aneshensel CS, Phelan JC, Bierman A. Editors. Handbooks of Sociology and Social Research. Dordrecht: Springer; 2013. p. 457-478. 
45. Aldwin CM, Park CL, Jeong YJ, Nath R. Differing pathways between religiousness, spirituality, and health: A self-regulation perspective. Psychology of Religion and Spirituality 2014; 6 (1): 9-21. doi: 10.1037/a0034416.

46. Rocha ACAL, Ciosak AI. Chronic desease in the elderly: Spirituality and coping. Rev Esc Enferm USP $2014 ; 48$ (Esp2): 87-93. doi: 10.1590/S0080-623420140000800014.

47. Bizik G, Picard M, Nijjar R, Tourjman V, McEwen BS, Lupien SJ, Juster RP. Allostatic Load as a Tool for Monitoring Physiological Dysregulations and Comorbidities in Patients with Severe Mental Illnesses. Harv Rev Psychiatry 2013 ; 21 (6): 296-313. doi: 10.1097/HRP.0000000000000012. 